\title{
Determinants of Money Supply in Nigeria
}

\section{Aderopo R. Adediyan ${ }^{1}$}

Studies on money supply determinants focus on the Classicists or Monetarists, Keynesians and post-Keynesians variables like income and money multiplier. This research extends the literature on money supply determinants to include the influence of financial liberalization on money supply with a reference to Nigeria between 1980 and 2019, using the Autoregressive Distributed Lag (ARDL) approach. Data used for the study were collected from the 2019 CBN Annual Statistical Bulletin. The study found that financial liberalization is an important factor in determining money supply in Nigeria, in addition to currency ratio, required reserve ratio and high-powered money. As a result, the extent of the liberalization of the financial sector matters in decisions on the regulation of money supply in the economy.

Keywords: Autoregressive distributed lag, financial liberalization, money supply determinants

JEL Classification: E5, E51, E52

DOI: $10.33429 /$ Cjas.11220.7/8

\section{Introduction}

A lot of factors determine money supply. For instance, in the traditional or classical model of money supply determination, to control the level of money supply, there are array of options, which includes alteration of the cash reserve requirement. Raising or lowering the cash reserve requirements or the deposits that are required of the commercial banks' to keep with the central bank or monetary authority can change the quantity of money supply. It is to be noted that the larger the commercial banks' deposit, the stronger is its capacity to generate more money. Therefore, the apex bank normally targets the deposit money/commercial banks deposit balances by raising the cash reserve requirement to regulate the growth of money stock that may possibly generate inflation in the economy.

Fractional reserve banking is also believed to determine money stock: "if only a small part of deposits is withdrawn from a bank during a period, the bank does not have to maintain reserves equal to deposits, but could increase its revenues by lending out a part or most of its deposits" (Handa, 2009). Additionally, the supply of money can be regulated via changes in liquidity ratio as well as money outside the bank (in the hands of the non-bank public)

\footnotetext{
${ }^{1}$ Department of Economics, University of Benin. Email: adediyan@yahoo.com, Phone no: $+2347057721315$
} 
through the bank discount rate. Changes in the banks' discount rate affect the money supply by affecting the volume of discount loans and the monetary base. A rise (fall) in discount loans increases (reduces) monetary base and expands (shrinks) money supply in the economy (Gashaw, 2014; Onwumere, Imo \& Ugwuanyi, 2012). Similarly, the money multiplier, a multiplicity of high-powered money, is believed to determine the level of money supply. A decrease or increase in the money multiplier results in a change in the money supply (Gashaw 2014; Bakare 2011).

In the Monetarists point of view, it is the "primate factor" that matters in the determination of money supply. The primate factor consists of monetary base (high-powered money), constituting currency and coins outside the banking system (i.e. notes and coins held by the non-banking public) plus the deposits of deposit money banks with the central bank, reserve and currency ratios. Different from the Classicists or Monetarists view, the Keynesians and Post Keynesians identified variables including income, interest rate and economic activities as factors critical to the determination of money supply. Furthermore, on money supply determinations, Handa (2009) submitted that irrespective of the way it is characterized, measured or assessed, the stock of money determination involves some participants. The core of them is the public and the commercial banks together with the central bank. The interaction of these three units and the significance of each in the determination of money supply depend on the state of the economy.

Nonetheless, a crucial factor that is also important in the determination of the quantity of money supply in addition to the aforementioned theoretically justified determinants but yet to be given considerable attention to is the influence of structural economic transformation or reform particularly the effect of financial liberalization reform. For example, according to Shaw (1973) and McKinnon (1973), a restriction on the financial sector in the form of a high reserve requirement, interest rate and direct credit ceiling hinders money flows, financial development and economic activities. These may affect the people's desire to hold currency relative to deposit. Financial regulation reduces the efficiency of the financial system which leads to a reduction in economic activities and income, and consequently, a contraction of money supply. This logically means that the supply of money may be high or low depending on whether financial liberalization policy is implemented.

Regrettably, there is a lack of empirical evidence on this relationship except for the study of 
Muhammad and Islam (2010) done in Bangladesh using a Least Square method - a static analysis even though the money supply process is dynamic in nature. Previous studies on the determinants of money supply centred largely around high-powered money and money multiplier (Lodha \& Lodha, 2012; Lone \& Yadav, 2016; Odior, 2013), reserve money, bank rate, and currency ratio (Tiwari, 2016; Shrestha, 2013; Muhammad \& Islam, 2010), income or GDP and interest rate (Ifionu \& Akinpelumi, 2013; Chigbu \& Okorontah, 2013) and other variables of the same or similar characteristics. Studies like Khan and Hye (2013) consider financial liberalization but as a determinant of money demand. The present study extends the existing literature on the money supply determinants particularly in Nigeria to include the role of financial liberalization on the supply of money using an Autoregressive Distributed Lag approach capturing the timing involved in the money supply process. Essentially, the general objective of this study is to assess the determinants of money supply in Nigeria.

The rest of the paper is as follows: Section 2 is the literature review, data and methodology are in Section 3, results and discussion are presented in Section 4 while Section 5 is for the conclusion and policy recommendations.

\section{Literature Review}

\subsection{Theoretical Literature}

In the classical or traditional model of money supply determination, a cluster of economic variables like minimum cash reserve ratio, currency ratio, bank reserve and liquidity ratio are the fundamental determinants of money supply (Handa, 2009). In the Monetarists view, the primate factors are the important variables to be considered in the money supply determination. In contrast, the Post-Keynesians hold that the rate of interest and real output or economic activities which affect the desire of the people to hold currency rather than deposits are what determine the level of money supply at a point in time (Fontana, 2003). According to Jhingan (2008), an alteration in the level of economic activities that affect the desire of the economic agents in terms of currency holding in relation to the deposits determines the supply of money. In this spirit, Handa (2009) concluded that the more people desire to hold currency, the lower the money supply will be.

Andersen and Jerry (1968) while analyzing the determinants of money supply identified "monetary base" as the core determinant of money supply. The study maintained that the monetary base or "high-powered money" is a useful concept for characterizing the behaviour 
of money supply. More so, a multiple of the monetary base has also been argued to be a determinant of money supply. Handa (2009) referred to the multiple of monetary base as the "money supply multiplier approach or model". Based on the multiplier approach, the supply of money is basically a multiplicity of the high-powered money. Odior (2013) opined that the multiplier model is a function of the currency ratio, the reserve ratio and the high-powered money (monetary base). The mathematical illustration of the money multiplier model provided by Goodhart (2017) is as in equation (1)

$$
M s \equiv\left(\frac{1+c r}{r r+c r}\right) H
$$

where $M s$ is the money supply, $r r$ is reserve ratio, $c r$ is the currency ratio and $H$ stands for high-powered money. However, as noted by Howells (2010), the multiplier approach is an identity rather than representing behavioural function; hence, inadequate.

The behavioural theory of the money supply determination improves upon the Base-Multiplier approach by taking into consideration the behaviour of the publicly held currency, the commercial or deposit money banks' reserves, the quantity of the money borrowed by the public and Banks coupled with the high-powered money that the apex bank desires to offer mostly in terms of the interest rate. In this regard, the money supply depends on the free reserves of the deposit money bank, in addition to the cash desired to be held by the public relative to deposit with respect to the interest rate. A free reserve, ceteris paribus, is a function of the opportunity cost of holding it. As the opportunity cost lessens, the free reserves demand would shrink; this, in turn, implies an increment in the money stock (Bain \& Howells, 2003; Handa, 2009).

Conversely, according to Thornton's model of the money stock determination: a model of non-commodity money, the Apex bank generates money by wedging the difference between the natural interest rate and the market interest rate. In the model, the demand for the real money is not affected by the wedge linking the natural rate and the market such that the price has to adjust to the level of the nominal money. In a different way, the Tinbergen model of money supply incorporated Keynes' theory of liquidity preference in the determination of money stock. The model presupposes that the Apex bank fixes the discount rate together with the value for the non-borrowed reserve. This model links the supply of money to the behaviour of banks' in a quest for the free reserves. The model explains further that demanding 
for free reserves by the banks is necessitated by banks' want of the interest. In a similar way, the Shaw (1973) and McKinnon (1973) deregulation framework which focuses on financial system liberalization hammered, among others, on liberalizing interest rate and the stoppage of direct credit ceiling to improve efficiency of banks and cash flows in the economy.

\subsection{Empirical Literature}

Globally, the empirical literature focuses much on the debate on income, output, interest rate, reserve and currency ratios, money multiplier and high-powered money as the determinants of money supply. Virtually all the studies find statistical support for these determinants, even though the degree of importance and preference for some of these variables may differ. For example, Shirvani and Bayram (2014) study the determinants of money supply in the United States (US). The Johansen co-integration and Dominance methods of analysis were employed. The study establishes that excess reserve and currency ratios are important determinants of money supply in the US. In India, Lodha and Lodha (2012) studied the money multiplier and high-powered money as the determinants of money stock. The study showed that the high-powered money and money multiplier positively contributed to the growth in money supply between 1981 and 2012.

Also, Lone and Yadav (2016) researched the money stock determination in India. The research suggests the high-powered money and the money multiplier determine money supply in India. In Nepal, Shrestha (2013) studied the process of the money supply. The research identified high powered-money as the core determinants of the stock of money. Currency ratio and the Multiplier also affect the supply of money. Similarly, Tiwari (2016) examined the money supply determinants in Nepal. The estimation technique adopted was the OLS method. The study identified reserved money as the most important money supply determinants in Nepal.

In Bangladesh, Muhammad and Islam (2010) empirically study the money stock function using autocorrelation correction Ordinary Least Square (OLS) approach. The research establishes that the Bank rate, financial liberalization and external resources control the level of money stock. In Ghana, Sanusi (2010) examines money supply determination. The study suggests that prior to the 1990s, fiscal deficits determine money supply; but, in the aftermaths of the 1990s, the banks net foreign assets are the major determinant of the supply of money. 
In Nigeria, Odior (2013) analyzed the supply of money. The study adopted a time-series GMM model. The study presumed that broad money supply depends upon changes in monetary base and the money multiplier. The results revealed a positive but partially stable relationship between the base money and money supply, and money multiplier and money supply. Bakare (2011) accessed the supply of money determinants with its impact on inflation. The research adopted a quasi-experimental research method for its analysis. The outcome of the study suggested that credit to the private individuals or sector is a positive determinant of money supply. Also, Chigbu and Okorontah (2013) explore whether the supply of money is exogenous. The research utilized annual data between 1970 and 2008 and the 2-Stage Least Square (2SLS), co-integration (Johansen), as well as the Granger-causality methods were used. The research confirmed that the real income and the interest rate co-integrate with the supply of money. The study equally showed that the money stock is controlled endogenously through a change in the level of real income, real rate of interest and value of money. Consequently, the study argued that although the monetary authority could influence the supply of money, it is the economic activity, however, that exerts a larger influence on the money stock variations.

Abakpa, Purokayo and Asaph (2018) investigate the money supply determinants in Nigeria. The study used the Autoregressive Distributed Lag Model, ARDL, approach. The study reported that among the variables of interest, only the GDP is found to significantly control money stock. In the same spirit, the study of Ifionu and Akinpelumi (2015), using the OLS technique, suggested GDP as a prime determinant of money stock in Nigeria between 1981 and 2013.

From the literature reviewed, it is well understood that money supply is determined by a change in the base money or high-powered money, interest rate, money multiplier, liquidity and reserve ratios or real income and output. These set of variables exceptionally perform well in the characterization of the behaviour of money supply both in the theoretical and empirical standpoints. However, what is not discussed in the literature is whether financial liberalization is also important in conjunction with these variables in the model of money supply determination particularly in Nigeria where financial liberalization is assumed to be a catalyst to financial system development upon which the effectiveness of monetary policy hinges. Indeed, financial liberalization may influence the rate of money circulation or the 
extent to which money supply changes in the economy.

Yet, Muhammad and Islam (2010) appeared to be the only study, carried out in Bangladesh, that consider but a skeletal effect of financial liberalization on money stock. Other studies like Mansaray and Swaray (2013) focus attention on financial liberalization's impact on money demand. Additionally, most of the studies on money supply determination in Nigeria are static analyses, even though the money supply involves a dynamic process that takes time; thus, inappropriate. This research built on earlier studies to address these gaps.

\section{Data and Methodology}

\subsection{Data}

Annual time-series data were employed in the analysis. The data were on money supply, high-powered money, liquidity ratio, currency ratio, interest rate and required reserve ratio which were gathered from the CBN Annual Statistical Bulletin available at https://www.cbn.gov.ng/documents/Statbulletin.asp. The sample period is between 1980 and 2019. The timeframe is crucial to the study following the implementation of financial liberalization policy in Nigeria in the 1980s.

\subsection{Model Specification}

In the view of Shaw (1973) and McKinnon (1973), a restriction on the financial system in the form of a high reserve requirement, interest rate and direct credit ceiling hinders money flows, financial development and economic activities which may affect the people's desire to hold currency. As a result, financial liberalization is expected to determine the quantity of money supply. Therefore, for this study, the empirical model built to explain the determinants of money supply in Nigeria augment the Classicists, Monetarist and post-Keynesian models of money supply determination by presupposing financial liberalization as, also, an important determinant of money supply, shown functionally in equation 2 .

$$
M s=f(F L)
$$

In equation 2, Ms represents money supply (proxy by broad money supply (M3)) and FL means financial liberalization. To capture financial liberalization, Shrestha and Chowdhury (2006) suggested the construction of arbitrary values. Thus, a dummy variable was constructed, coded as 1 for the period financial liberalization is adopted and 0 if otherwise. Financial liberalization was adopted in 1986 in Nigeria, but its effect was not felt immediately. 
Therefore, 1986 downward is classified as pre-financial liberalization period, coded as 0 and 1987 onward is coded as 1 (financial liberalization period). Fowowe (2008), Mansaray and Swaray (2013) and Khan and Hye (2013) used a dummy variable to measure financial liberalization. In the spirit of the Classicists, Monetarist and post-Keynesian, variables especially reserve ratio, interest rate, high-powered money, liquidity ratio and currency ratio determine money supply. Therefore, equation 2 is re-stated as

$$
M s=f(R R, H, L R, C R, R, F L)
$$

In equation 3, Ms and FL are as earlier defined. RR is the reserve ratio, $\mathrm{H}$ stands for highpowered money (monetary base), LR is liquidity ratio, CR means currency deposit ratio (a fraction of currency in circulation to total deposit), $\mathrm{R}$ is interest rate (money market interest rate, proxy by Treasury bill rate).

In an econometric form, equation 4 becomes:

$$
I n M s_{t}=\alpha_{0}+\alpha_{1} R R_{t}+\alpha_{2} I n H_{t}+\alpha_{3} L R_{t}+\alpha_{4} C R_{t}+\alpha_{5} R_{t}+\alpha_{6} F L_{t}+\mu_{t}
$$

where $\mu$ stands for the error term, $\alpha_{0}, \alpha_{1}, \alpha_{2}, \alpha_{3}, \alpha_{4}, \alpha_{5}$ and $\alpha_{6}$ are parameters, In means logarithms, and $t$ implies time. It is expected that $\alpha_{1}, \alpha_{3}, \alpha_{4}, \alpha_{5}<0 ; \alpha_{2}, \alpha_{6}>0$.

The study hypothesized that financial liberalization positively determines money supply owing to its positive impact on income and economic activities in the literature. Note that equation 3 is a semi-log model since some of the variables like LR are in ratio. In the case of ratio variables, a further transformation distorts the variables' normal distribution property among others, therefore, no further transformation is applied.

\subsection{Estimation Method}

The study adopted the Autoregressive Distributed Lag (ARDL) approach. The ARDL is a dynamic estimation method that produces efficient estimates even when the variables of the study exhibit different order of integration such as zero (0) and one (1) compared to other methods like OLS frequently used in the previous studies. Also, the effect of an adjustment in the money supply to a change in its determinants may take time and not instantaneous, the ARDL approach, in this case, is suitable for such a model. The ARDL method variant of equation 3 is as in equation 4 where lack of prior knowledge of the direction of the long run 
relationship among the variables is presumed.

$$
\begin{aligned}
\Delta \operatorname{InMs}_{t}= & \beta_{0}+\sum_{\pi=1}^{k} a \Delta \ln M s_{(t-\pi)}+\sum_{\pi=0}^{k} b \Delta R R_{(t-\pi)}+\sum_{\pi=0}^{k} c \Delta \ln H_{(t-\pi)} \\
& +\sum_{\pi=0}^{k} d \Delta L R_{(t-\pi)}+\sum_{\pi=0}^{k} e \Delta C R_{(t-\pi)}+\sum_{\pi=0}^{k} f \Delta R_{(t-\pi)}+\sum_{\pi=0}^{k} g \Delta F L_{(t-\pi)} \\
& +\Upsilon_{1} \ln M s_{(t-1)}+\Upsilon_{2} R R_{(t-1)}+\Upsilon_{3} \ln H_{(t-1)}+\Upsilon_{4} L R_{(t-1)}+\Upsilon_{5} C R_{(t-1)} \\
& +\Upsilon_{6} R_{(t-1)}+\Upsilon_{7} F L_{(t-1)}+\varepsilon_{t}
\end{aligned}
$$

The order of lag is selected by Akaike info criterion (AIC). To establish the existence of co-integration, ARDL Bound test is conducted on equation 5. In the case of the existence of co-integration, (5) is broken down into a parsimonious long run and short run models. The parsimonious long run model is specified in equation 6

$$
\operatorname{In}\left(M s_{t}\right)=\gamma_{0}+\gamma_{1} R R_{t}+\gamma_{2} \ln H_{t}+\gamma_{3} L R_{t}+\gamma_{4} C R_{t}+\gamma_{5} R_{t}+\gamma_{6} F L_{t}+\mu_{t}
$$

In equation $6, \gamma_{0}, \gamma_{1}, \gamma_{2}, \gamma_{3}, \gamma_{4}, \gamma_{5}$ and $\gamma_{6}$ are the long run parameters.

On the other hand, the short run model is represented in equation 7

$$
\begin{aligned}
\Delta\left(\operatorname{In}\left(M s_{t}\right)\right)= & \theta_{0}+\sum_{\pi=1}^{\mathrm{a}} \theta_{1} \Delta\left(\operatorname{lnM} s_{(t-\pi)}\right)+\sum_{\pi=0}^{b} \theta_{2} \Delta\left(R R_{(t-\pi)}\right)+\sum_{\pi=0}^{c} \theta_{3} \Delta\left(\ln H_{(t-\pi)}\right) \\
& +\sum_{\pi=0}^{d} \theta_{4} \Delta\left(L R_{(t-\pi)}\right)+\sum_{\pi=0}^{e} \theta_{5} \Delta\left(C R_{(t-\pi)}\right)+\sum_{\pi=0}^{f} \theta_{6} \Delta\left(R_{(t-\pi)}\right) \\
& +\sum_{\pi=0}^{f} \theta_{7} \Delta\left(F L_{(t-\pi)}\right)+\omega \mathrm{ECM}_{(\mathrm{t}-1)}+v_{t}
\end{aligned}
$$

In equation $7, \Delta$ means the first-difference, $\theta_{0}, \theta_{1}, \theta_{2}, \ldots, \theta_{7}$ are the short run parameters. The $\omega$ is the rate of correction of the short run disequilibrium in the long run. The coefficient, $\omega$ is expected to be less than one (1), negative and statistically significant. For critical decisionmaking on the state of co-integration of the study's variables, a stationarity test is conducted using the Augmented Dickey-Fuller test to check the property of each of the variables.

\section{Stability Test}

To verify the stability of the estimated coefficients of the model, the Cumulative Sum of Square, CUSUMSQ, and Cumulative Sum, CUSUM, were used. For a stable model, the CUSUMSQ statistic line is expected to fall within the lower and upper bounds at a significance level of 5 per cent (Tule et al., 2018). This also applies to the CUSUM. 


\section{Result and Discussion}

The summary of the ADF stationarity test reported in Table 1 indicates that all the variables except liquidity ratio and interest rate are stationary after the first difference at a level of 5 per cent. The interest rate and liquidity ratio are level-stationary variables at a 10 per cent level. Consequently, the variables of the study are level and first-differenced stationary.

Table 1: ADF Stationarity test results

\begin{tabular}{|c|c|c|c|c|c|}
\hline \multirow[t]{2}{*}{ Variables } & \multirow{2}{*}{$\begin{array}{l}\text { Level } \\
\text { Constant }\end{array}$} & \multicolumn{3}{|c|}{$1^{s t}$ difference } & \multirow[t]{2}{*}{ Remark } \\
\hline & & $\begin{array}{l}\text { Constant\& } \\
\text { Trend }\end{array}$ & Constant & $\begin{array}{l}\text { Constant \& } \\
\text { Trend }\end{array}$ & \\
\hline $\ln (\mathrm{Ms})$ & -0.250023 & -1.269453 & $-4.194161 *$ & $-4.157471 *$ & $\mathrm{I}(1)$ \\
\hline $\ln (\mathrm{H})$ & -1.457940 & -1.755869 & $-3.853775^{*}$ & $3.863852 *$ & $\mathrm{I}(1)$ \\
\hline $\mathrm{RR}$ & -0.294232 & -1.767988 & $-5.080577 *$ & $-5.317937 *$ & $\mathrm{I}(1)$ \\
\hline CR & -1.248672 & -1.638220 & $-4.678355^{*}$ & $-4.533778 *$ & $\mathrm{I}(1)$ \\
\hline $\mathrm{R}$ & $-2.986393 *$ & -2.963417 & $-7.257060 *$ & $-7.248590 *$ & $\mathrm{I}(0)$ \\
\hline LR & $-2.922732 * *$ & $-2.979797 *$ & $-6.431729 *$ & $-6.392639 *$ & $\mathrm{I}(0)$ \\
\hline
\end{tabular}

\section{ARDL Model Selection}

To investigate the determinants of money supply in Nigeria, first, the basic optimal model is fitted as summarized in Table. It is a fitted model from which the short run and long run parameter estimates are derived. 
Table 2: ARDL Selected Model (2, 1, 3, 3, 2, 3)

\begin{tabular}{|c|c|c|c|c|}
\hline Regressors & Coefficient & Std. Error & t-Statistic & Prob. \\
\hline $\ln \mathrm{Ms}(-1)$ & 0.095 & 0.244 & 0.391 & 0.701 \\
\hline $\ln \mathrm{Ms}(-2)$ & $0.344^{*}$ & 0.176 & 1.951 & 0.069 \\
\hline $\ln \mathrm{H}$ & $0.366 * * *$ & 0.090 & 4.054 & 0.001 \\
\hline $\ln \mathrm{H}(-1)$ & 0.225 & 0.150 & 1.500 & 0.153 \\
\hline $\mathrm{CR}$ & 0.108 & 0.190 & 0.570 & 0.577 \\
\hline $\mathrm{CR}(-1)$ & -0.004 & 0.242 & -0.017 & 0.987 \\
\hline $\mathrm{CR}(-2)$ & -0.009 & 0.235 & -0.036 & 0.971 \\
\hline $\mathrm{CR}(-3)$ & $-0.449 * *$ & 0.196 & -2.292 & 0.034 \\
\hline LR & -0.002 & 0.002 & -1.40 & 0.181 \\
\hline $\operatorname{LR}(-1)$ & $0.007 * *$ & 0.002 & 2.813 & 0.013 \\
\hline $\operatorname{LR}(-2)$ & -0.002 & 0.002 & -1.066 & 0.302 \\
\hline $\operatorname{LR}(-3)$ & -0.003 & 0.002 & -1.496 & 0.164 \\
\hline $\mathrm{RR}$ & $-0.031 * * *$ & 0.007 & -4.182 & 0.001 \\
\hline $\mathrm{RR}(-1)$ & 0.005 & 0.010 & 0.513 & 0.615 \\
\hline $\mathrm{RR}(-2)$ & 0.012 & 0.007 & 1.707 & 0.107 \\
\hline $\mathrm{R}$ & 0.005 & 0.004 & 1.034 & 0.315 \\
\hline $\mathrm{R}(-1)$ & -0.007 & 0.004 & -1.565 & 0.137 \\
\hline $\mathrm{R}(-2)$ & $-0.016 * *$ & 0.006 & -2.942 & 0.010 \\
\hline$R(-3)$ & -0.006 & 0.005 & -1.304 & 0.211 \\
\hline $\mathrm{FL}$ & $0.260 * * *$ & 0.079 & 3.273 & 0.005 \\
\hline $\mathrm{C}$ & $1.076 * * *$ & 0.317 & 3.390 & 0.004 \\
\hline $\mathrm{R}^{2}$ & 0.999748 & \multicolumn{2}{|c|}{ Mean dependent var } & 6.896122 \\
\hline Adjusted $\mathrm{R}^{2}$ & 0.999432 & \multicolumn{2}{|c|}{ S.D. dependent var } & 2.538136 \\
\hline Regression S.E. & 0.060474 & \multicolumn{2}{|c|}{ Akaike info. criterion } & -2.476393 \\
\hline Sum squared resid & 0.058514 & \multicolumn{2}{|c|}{ Schwarz criterion } & -1.562089 \\
\hline Log likelihood & 66.81328 & \multicolumn{2}{|c|}{ Hannan-Quinn criter. } & -2.154058 \\
\hline F-statistic & 3169.948 & \multicolumn{2}{|c|}{ Durbin-Watson stat } & 2.014983 \\
\hline Prob(F-statistic) & 0.000000 & & & \\
\hline
\end{tabular}

Note: $*(* *) * * *$ means significant at $10 \%(5 \%) 1 \%$

Source: Calculated by the Author

\section{ARDL Bound Test of Co-integration}

Through the estimated model highlighted in Table 2, the study tests for a long-run relationship among the variables using Bound test. Since the F-statistics value of 5.311is larger than the upper-class limit of 3.920, the outcome of the test, summed up in Table 3, means that the null hypothesis of no co-integration among the variables is rejected at least at a level of 5 Per cent. Hence, the variables trend together in the long run.

Since the co-integration result in Table 3 suggests a long run relationship among the variables, the estimated long-run and short-run coefficients are presented in Tables 4 and 5. 
Table 3: ARDL Bound Co-integration Test on the Determinants of Money Supply (Restricted intercept with no trend)

\begin{tabular}{lll}
\hline Critical Level & $\mathrm{I}(0)$ & $\mathrm{I}(1)$ \\
\hline $1 \%$ & 3.657 & 5.256 \\
$5 \%$ & 2.734 & 3.920 \\
$10 \%$ & 2.306 & 3.353 \\
$F_{(\ln M s)}=5.311$ & \\
\hline \multicolumn{2}{l}{ N.B: K=5; the critical values are from Narayan(2004) } \\
\multicolumn{2}{l}{ Author's computation }
\end{tabular}

\section{Long Run and Short Run Analyses}

From the long-run result reported in Table 4, the long run coefficient of financial liberalization is positive and statistically significant at a 5 per cent level. That is, there is sufficient statistical evidence that financial liberalization positively induces money supply in the long run. The long run magnitude of impact of financial liberalization effectiveness on money supply is roughly 2.382 (i.e. $1.919+0.463$ ). Assuming zero effect of other factors in the model, it thus follows from the estimated positive coefficient of financial liberalization that in the long run there will be an increase in the volume of money stock by about 2.38 per cent if financial liberalization index is strengthen by a unit in Nigeria.The positive impact of financial liberalization estimated is in line with the study's prediction and conforms to the conclusion of the study of Muhammad and Islam (2010) done in Bangladesh that financial liberalization promotes money supply. In the case of other regressors in the model, as expected, high powered-money and money supply have a long run positive relationship. The long run estimated coefficient of high-powered money is about 1.05 . The size of the sensitivity of money supply to a change in the level of high-powered money is almost equal to unity (one) in the long run, positive and statistically significant at a level of 5 per cent. Holding other factors in the model fixed, the coefficient suggests roughly a proportional relationship between money supply and the high-powered money in the long run in Nigeria. That is money supply changes roughly proportionately with a change in the level of high-powered money. This calls to mind the importance of high-powered money as a good policy variable to manage the total volume of money supply in Nigeria in the long run. The estimated positive relationship between the high-powered money and money supply is in accordance with Shrestha (2013) findings. On the other side, money supply showed up to 0.6 per cent per change in the ratio of currency to deposit in the long run. That is, in the long run, a unit increment in the currency ratio will reduce money supply by roughly 0.6 per cent yearly. Also, the liquidity ratio, in the long run, 
turns out with the expected sign (negative), but not statistically significant at 5 per cent level.

Table 4: Long Run Coefficients

\begin{tabular}{lllll} 
Regressors & Coefficient & Std. Error & t-Statistic & Prob. \\
\hline $\ln \mathrm{H}$ & $1.054 * * *$ & 0.030 & 35.313 & 0.000 \\
$\mathrm{CR}$ & $-0.631 * * *$ & 0.175 & -3.609 & 0.002 \\
$\mathrm{LR}$ & -0.001 & 0.005 & -0.120 & 0.891 \\
$\mathrm{RR}$ & $-0.025 * * *$ & 0.008 & -2.969 & 0.009 \\
$\mathrm{R}$ & $-0.044 * * *$ & 0.012 & -3.782 & 0.002 \\
$\mathrm{FL}$ & $0.463 * * *$ & 0.131 & 3.539 & 0.003 \\
$\mathrm{C}$ & $1.919 * * *$ & 0.308 & 6.240 & 0.000 \\
\hline *** means significant at 5\%(1\%) & & \\
\multicolumn{5}{l}{ Source: Calculated by the Author }
\end{tabular}

Further, the reserve ratio is negatively related to the level of the money stock and significant at 5 per cent in the long run. This technically implies that whenever the Apex bank raises the reserve ratio, the total quantity of money supply will reduce. For a unit rise in the ratio of reserve to deposit, in the long run, the expected decrease in total money stock hovers around 0.02 per cent a year. At a level of 5per cent, the long run impact of interest rate is negative and statistically significant. Because an increase in the rate of interest reduces the fraction of money people hold, decreases economic activities and money supply. The short run result is presented in Table 5.

In the short run, the impact of financial liberalization on money stock is positive and significant at 5 per cent. As a result, the financial liberalization variable positively determines the growth of money supply in the short run in Nigeria. The level of the short run impact of financial liberalization on money supply is approximately $2.179(1.919+0.260)$ which means that money supply will rise up to a 2.18 per cent level if the intensity of financial liberalization policy is further deepened by one unit in Nigeria in the short run. Again, the result validates the positive effect of financial liberalization reported in Bangladesh by Muhammad and Islam (2010). In addition to the primary explanatory variable of interest, the impact of high-powered money is positive and statistically significant but weighs less on money supply in the short run than in the long run. The short run coefficient of high-powered money is about 0.37 ; thus, less sensitive in the short run money supply determination model compared to the long run.The short run current and the immediate lagged value of the currency ratio, contrary to expectation, are positive and statistically insignificant which contradicts the findings of Shirvani and Bayran (2014). However, a second lagged value of currency ratio, 
although positive, is statistically significant at a 5 per cent level. Therefore, it follows that increase in currency ratio may not lead to a reduction in the quantity of money supply. The unexpected positive relationship between the money stock and currency ratio is likely as a result of the future expectation by the economic agent. The liquidity ratio variable is also positive and not statistically different from zero. In consequent, the liquidity ratio reduction or increase is unlikely to impact money supply significantly in the short run. Nonetheless, reserve ratio has a negative and statistically significant effect on money supply in the short run. To ease money supply up to 0.03 per cent in the short run, reserve ratio must be reduced by at least a unit. However, the coefficient is not significant with lag. Additionally, the current rate of interest, in the short run, plays an insignificant positive role in the money supply determination model. Finally, the result showed that the growth of money stock adjusts to a steady-state (equilibrium) with lags up to 56 per cent within a year.

Table 5: Short run Estimates

\begin{tabular}{lllll} 
Regressors & Coefficient & Std. Error & t-Statistic & Prob. \\
\hline $\mathrm{D}(\ln \mathrm{Ms}(-1))$ & $-0.344 * *$ & 0.176 & -1.951 & 0.069 \\
$\mathrm{D}(\ln \mathrm{H})$ & $0.366 * * *$ & 0.090 & 4.054 & 0.001 \\
$\mathrm{D}(\mathrm{CR})$ & 0.108 & 0.190 & 0.570 & 0.577 \\
$\mathrm{D}(\mathrm{CR}(-1))$ & 0.009 & 0.235 & 0.036 & 0.971 \\
$\mathrm{D}(\mathrm{CR}(-2))$ & $0.449 * *$ & 0.196 & 2.292 & 0.036 \\
$\mathrm{D}(\mathrm{LR})$ & -0.002 & 0.002 & -1.400 & 0.181 \\
$\mathrm{D}(\mathrm{LR}(-1))$ & 0.002 & 0.002 & 1.066 & 0.302 \\
$\mathrm{D}(\mathrm{LR}(-2))$ & 0.003 & 0.002 & 1.459672 & 0.164 \\
$\mathrm{D}(\mathrm{RR})$ & $-0.031 * * *$ & 0.007 & -4.182014 & 0.001 \\
$\mathrm{D}(\mathrm{RR}(-1))$ & -0.012 & 0.007 & -1.707146 & 0.107 \\
$\mathrm{D}(\mathrm{R})$ & 0.005 & 0.004 & 1.033861 & 0.317 \\
$\mathrm{D}(\mathrm{R}(-1))$ & $0.016 * *$ & 0.006 & 2.941976 & 0.010 \\
$\mathrm{D}(\mathrm{R}(-2))$ & 0.006 & 0.005 & 1.304079 & 0.211 \\
$\mathrm{D}(\mathrm{FL})$ & $0.260 * * *$ & 0.079 & 3.273291 & 0.005 \\
CointEq(-1) & $-0.560 * * *$ & 0.120 & -5.107743 & 0.000 \\
\hline$*(* *) * * *$ means significant at $10 \%(5 \%) 1 \%$ & & \\
Source: Calculated by the Author & & & \\
& \multicolumn{5}{l}{ Cor $)$} & & &
\end{tabular}

\section{Model Stability and Diagnostic Test}

The model stability test outcome obtained through the CUSUM and the CUSUMSQ graphs are illustrated in Figures1 and 2 in the Appendix. The two graphs (Figure 1 and 2) indicate that the parameters of the model are stable.

The results of the diagnostic test conducted to ensure the validity of the estimated model are 
as summarized in Tables 6 to 9. In Table 6 , it is seen that the null hypothesis of homoscedasticity cannot be rejected since all the three test statistics are statistically insignificant.

Table 6: White Heteroskedasticity Test

\begin{tabular}{llll} 
F-statistic & 1.003 & Prob. F(20,16) & 0.518 \\
Obs*R_squared & 20.586 & Prob. X ${ }^{2}(20)$ & 0.446 \\
Scaled explained SS & 2.660 & Prob. X ${ }^{2}(20)$ & 0.997 \\
\hline
\end{tabular}

Source: Calculated by the Author

Additionally, in the result in Table 7, both F-statistics and Obs*R-squared statistics indicate that there is no autocorrelation in the model.

\begin{tabular}{llll}
\multicolumn{4}{l}{ Table 7: Breusch-Godfrey LM Autocorrelation Test } \\
\hline F-statistic & 0.260 & Prob. F(2,20) & 0.774 \\
Obs*R_squared & 1.327 & Prob. $X^{2}(2)$ & 0.515 \\
\hline
\end{tabular}

Source: Calculated by the Author

Furthermore, the result summarized in Table 8 implies that the residual of the model is normally distributed.

Table 8: Normality (Jarque-Bera) Test

\begin{tabular}{lrr}
\hline Statistic 0.661 & Prob. & 0.719 \\
\hline Source: Calculated by the Author &
\end{tabular}

Lastly, the result in Table 9 indicated that the model passed model misspecification test as shown by the p-value.

Table 9: Ramsey RESET (Model Misspecification) Test

\begin{tabular}{lccc}
\hline & Value & df & Prob. \\
\hline t-statistic & 0.865 & 15 & 0.401 \\
F-statistic & 0.7477 & $(1,15)$ & 0.401 \\
\hline \multicolumn{4}{l}{ Source: Calculated by the Author }
\end{tabular}

As a result, the estimates of the model are valid for policy analysis.

\section{Conclusion and Policy Recommendations}

In conclusion, ceteris paribus, financial liberalization is a positive and significant determinant of money supply in Nigeria. The positive impact of financial liberalization is valid, based on the estimated model, in the long run and short run. This is in addition to the commonly identified determinants of money supply in the literature: the required reserve ratio, high-powered money, interest rate and currency ratio as empirically valid determinants of the quantity of 
money stock in Nigeria. Consequently, financial liberalization is suitable for effective regulation of money supply in Nigeria. That is, for the purpose of achieving better economic stability through the management of money stock, enhancing financial liberalization is important in addition to the high-powered money control and the Central bank's effort in the regulation of reserve ratio, currency ratio and fixing of the rate of interest.

\section{References}

Abakpa, A., Purokayo, S. G. \& Asaph, P. P. (2018). Analysis of the determinants of money supply in Nigeria (1981-2015). International Journal of Scientific Research. 3(2): 21-38. http://journalijsr.com/content/2018/IJSR70.pdf

Andersen, L. C. \& Jerry, L. J. (1968). The monetary base-explanation and analytical use. Review, Federal Reserve Bank of St. Louis. 50(8):7-11.

Bain, K. \& Howells, P. (2003). Monetary economics: Policy and its theoretical basis. New York. Palgrave Macmillan publisher.

Bakare, A. S. (2011). An empirical study of the determinants of money supply growth and its effects on inflation rate in Nigeria. Journal of Research in International Business and Management. 1(5): 124-129.

CBN Annual Statistical Bulletin. https://www.cbn.gov.ng/documents/Statbulletin.asp ,Accessed on July 17,2020

Chigbu, E. E., \& Okorontah, C. F. (2013). Exogeneity of money supply evidence from Nigeria. Journal of Research in Economics and International Finance. 2(4): 62-67

Ching, H. D. (2001). Endogenous money -A structural model of monetary base. The South East Asian Central Banks, Research and Training Centre (The SEACEN Centre), Kuala Lumpur, Malaysia. Occasional Paper, No. 52.

Fontana, G. (2013). Post-Keynesian approaches to endogenous money: A time framework explanation. Review of Political Economy, 15(3): 291-314

Fowowe, B. (2008).Financial liberalization policies and economic growth: Panel data evidence from sub-Saharan Africa. African Development Review. 20(3): 549-574

Gashaw, D. (2014). "Can Monetary Authority Controle the Stock of Money Supply in Ethiopia: An Empirical Investigation". Addis Ababa University. Unpublished Thesis, Economic Department.

Goodhart, C. A. E. (2017). The determination of the money supply flexibility versus control. Manchester School. 85(2):33-56 
Handa, J. (2009). Monetary economics. $2^{\text {nd }}$ Ed. New York. Routledge publisher.

Howells, P. (2010). Money supply in macroeconomics. In: Issues in economic thought. Nova Science Publishers, Inc.

Ifionu, E. \& Akinpelumi, O. F.(2015). Macroeconomic variables and money supply: Evidence from Nigeria. African Research Review. 9(4):288-307

Jhingan, M. L. (2008). Money, banking, international trade and public finance. $8^{\text {th }}$ ed. Delhi.Vrinda Publications (P) Ltd.

Khan, R. E. \& Hye, Q. M. A (2013). Financial liberalization and demand for money: A case of Pakistan. Journal of Developing Areas. 47(2):175-198

Lodha, S. L. \& Lodha, M. (2012). Money stock determinants: high powered money and money multiplier. Journal of Economics and Sustainable Development, 3(9):83-96.

Lone, N. A \& Yadav, D. K. (2016). Determinants of money supply in India: A post reform scenario. IOSR Journal of Economics and Finance (IOSR-JEF). 7(5): 39-48.

Mansaray, M. \& Swaray, S. (2013). Financial liberalization, monetary policy and money demand in Sierra Leone. Journal of Monetary and Economic Integration. 12(2):61-90

McKinnon, R. I. (1973). Money and capital in economic development. Washington DC. The Brookings Institution.

Muhammad, M. A. \& Islam M. I. (2010). Money supply function for Bangladesh: An Empirical analysis. AIUB Bus Econ Working Paper Series, No 2010-01,

Narayan, P. K. (2004). Reformulating critical values for the bounds f-statistics approach to cointegration: An application to the tourism demand model for Fiji. Department of Economics, Monash University Discussion Papers. ISSN 1441-5429.Retrieved from https://www.researchgate.net/publication/268048533 on April 15, 2020.

Odior, E. S. (2013). Pure portfolio approach to money supply determination in Nigeria: A generalized method of moments approach. Journal of Finance \& Economics. 1(1):1026

Onwumere J. U. J., Imo .G. \& Ugwuanyi, U. B. (2012). "Does open market operations as a monetary policy tool has an impact on price stability in nigeria?" Research Journal of Finance and Accounting. 3(10): 43-48

Sanusi, A. R (2010). An empirical analysis of the money supply process in Ghana: 19832006. Abuja Journal of Banking and Finance. 2(1): 115 - 128.

Shaw, E. S. (1973). Financial deeping in economic development. New York: Oxford University Press 
Shirvani, H. M \& Bayram, S.G (2014). The relative importance of the determinants of the US money supply. Research in Business and Economics Journal.1-16 Available at https://www.aabri.com/manuscripts/131537.pdf

Shrestha, P. K. (2013). An empirical analysis of the money supply process in Nepal. NRB Economic Review, 17-42.

Shrestha, M. B. \& Chowdhury, K (2006). Financial liberalization index for Nepal. International Journal of Applied Econometrics and Quantitative Studies. 3(1):41-54

Tiwari, S. A. (2016). Money supply determinants in Nepal: A macro analysis. Economic Literature. 13:55-60

Tule, M. K., Okpanachi, U. M., Ogiji, P.\& Usman, N. (2018). A reassessment of money demand in Nigeria.CBN Journal of Applied Statistics. 9(1):47-75

\section{Appendix}

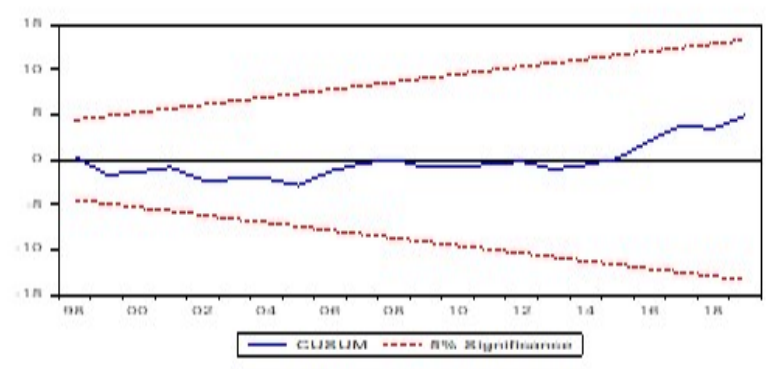

Figure. 1. CUSUM Graph

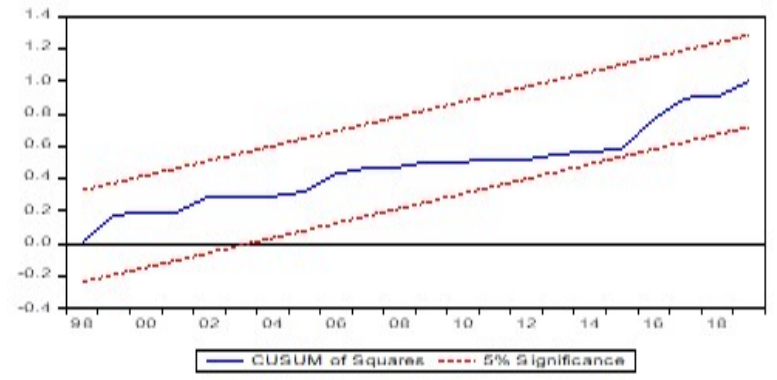

Figure. 2. CUSUM Graph 
Correlation among the Variables of Study

\begin{tabular}{|c|c|c|c|c|c|c|}
\hline $\begin{array}{l}\text { Correlation } \\
\text { t-Statistic }\end{array}$ & & & & & & \\
\hline LnMs & $\begin{array}{l}\text { LnMs } \\
1.000000\end{array}$ & $\mathrm{LnH}$ & CR & LR & RR & FL \\
\hline $\mathrm{LnH}$ & $\begin{array}{l}0.991229 \\
46.23596\end{array}$ & $\begin{array}{l}1.000000 \\
-\end{array}$ & & & & \\
\hline CR & $\begin{array}{l}-0.662453 \\
-5.451367\end{array}$ & $\begin{array}{l}-0.576219 \\
-4.346108\end{array}$ & $\begin{array}{l}1.000000 \\
-\end{array}$ & & & \\
\hline LR & $\begin{array}{l}0.146008 \\
0.909804\end{array}$ & $\begin{array}{l}0.153114 \\
0.955122\end{array}$ & $\begin{array}{l}-0.147569 \\
-0.919749\end{array}$ & $\begin{array}{l}1.000000 \\
-\end{array}$ & & \\
\hline RR & $\begin{array}{l}0.617475 \\
4.839080\end{array}$ & $\begin{array}{l}0.637142 \\
5.095848\end{array}$ & $\begin{array}{l}-0.451735 \\
-3.121308\end{array}$ & $\begin{array}{l}0.378639 \\
2.521850\end{array}$ & $\begin{array}{l}1.000000 \\
-\end{array}$ & \\
\hline FL & $\begin{array}{l}0.641264 \\
5.151715\end{array}$ & $\begin{array}{l}0.684325 \\
5.785244\end{array}$ & $\begin{array}{l}-0.076077 \\
-0.470332\end{array}$ & $\begin{array}{l}-0.091756 \\
-0.568019\end{array}$ & $\begin{array}{l}0.180504 \\
1.131286\end{array}$ & $\begin{array}{l}1.000000 \\
-\end{array}$ \\
\hline $\mathrm{R}$ & $\begin{array}{l}-0.056653 \\
-0.349796\end{array}$ & $\begin{array}{l}-0.104626 \\
-0.648519\end{array}$ & $\begin{array}{l}0.453449 \\
3.136211\end{array}$ & $\begin{array}{l}-0.162293 \\
-1.013885\end{array}$ & $\begin{array}{l}-0.315366 \\
-2.048586\end{array}$ & $\begin{array}{l}0.436346 \\
2.989424\end{array}$ \\
\hline
\end{tabular}

